удк [378:613-047.22]:796.011.3

Борис Максимчук

Ізмаїльський державний гуманітарний університет

ORCID ID 0000-0002-4168-1223

Володимир Жуков

Сумський державний педагогічний

університет імені A. C. Макаренка

ORCID ID 0000-0003-1392-7211

Сергій Ящук

Уманський державний педагогічний університет імені Павла Тичини

ORCID ID 0000-0002-8309-5898

Майя Зубаль

Кам'янець-Подільський національний університет імені Івана Огієнка ORCID ID 0000-0002-8145-5263

Василь Кевпанич

Ужгородський національний університет

ORCID ID0000-0002-0706-5646

DOI 10.24139/2312-5993/2019.07/234-243

\title{
АКТИВІЗАЦІЯ МОТИВАЦІЇ МАЙБУТНІХ ВИКЛАДАЧІВ ФІЗИЧНОГО ВИХОВАННЯ І СПОРТУ В СФЕРІ ЕКОЛОГІЧНОГО ТУРИЗМУ
}

Мотивувати учня може тільки той викладач, екологічні компетентності й особистісні властивості якого виглядають природними та фоновими стосовно власне дидактичної діяльності. Екстремумами екологічної активності виступають тільки пограничні або когнітивно дисонансні моменти, інакше студент, який рефрлексивно сприймає фрізичні та психологічні виміри, може побачити «фральщ» або навмисну доцільність у діях педагога. Мотивація студентів до екологічної активності, діяльності та самовдосконалення містить в основі ціннісні (аксіологічні) імперативи і мотиви. Мета статті полягає в теоретичному обгрунтуванні ефективності активізації мотивації майбутніх викладачів фрізичного виховання і спорту в сфері екологічного туризму.

Ключові слова: компетентність, студенти, заклади вищої освіти, активне навчання, методи навчання, мотиви, цінності, вища школа.

Постановка проблеми. Компетентність і мотивація - два потужних внутрішніх ресурси, які акмеологічно ведуть людину до високої екологічної й фізичної планки, долаючи лінь, психологічну резистентність, матеріальні перешкоди тощо.

Методологічно фонова й наскрізна імплементація екологічної складової має бути ненав'язливою й іманентною. Викладач же ставить досягнення оптимальних цілей, а високо вмотивований учень або студент - 
високих. Завдяки вмотивованості й компетентному впливу можна досягнути зміни поведінки (подолання паттернів, стереотипів, звичок, які як правило і підтримують антиекологічну активність) (Максимчук та ін., 2018). Тактично дієвим $€$ формування установок, що змінюють конфігурацію поведінки. Завдяки цьому в суб'єктів освітнього процесу з часом і поступово модифікується реакція, активність, поведінка, діяльність, світогляд тощо. Згідно з експериментом, найефективнішим екологічним впливом на вихованця $\epsilon$ мотивація й модифікація вже наявних у нього позитивних інтенцій, установок, потреб, зацікавлень (Куртова та ін., 2018).

Установлено, що природа та зміст екологічної компетентності особистості визначають преферентність активного навчання, що стає можливим за умови використання інтерактивних методів його організації.

Організація навчального процесу в інтерактивній формі змінює звичну його логіку: процес вибудовується не від теорії до практики, а від формування нового досвіду до його теоретичного осмислення через застосування інтерактивних методів навчання. Застосування інтерактивних методів навчання актуалізує ситуативні мотиви діяльності; активність, умотивована цими спонуками, веде до формування усталених мотивів і цінностей, що лежать у семантичному полі екологічної компетентності особистості. Використання методів інтерактивного навчання збагачує досвід самостійної діяльності й особистої відповідальності студентів (Волошин, 2012).

Ефективність освітнього процесу в системі вищої освіти з формування екологічної компетентності майбутніх викладачів у процесі фізичного виховання забезпечується оптимальним підходом до побудови його структури, змісту, що реалізується за рахунок використання методів навчання та виховання, форм роботи зі студентами (Пакушина, 2010).

3 філософської, науково-педагогічної та життєвої практики відомо, що глибинна і сильна мотивація перемагає перешкоди, психологічну резистенцію, вікову специфіку поведінки й веде людину до досягнення найвищих цілей. Попри патетичне звучання фраз «найвищі цілі», «перемога над собою» тощо все ж видається можливим у процесі довготривалого поступального цілеспрямованого формування мотивації вести вихованця (як учня, так і студента, якщо не до найвищої, то принаймні до оптимальної мети).

Насправді подають документи до приймальних комісій більша кількість і часто вступають за залишковим принципом: «Йду в педагогічний університет, бо не вступив у престижніший». Це серйозна мотиваційна й передовсім демографічна проблема: через брак абітурієнтів, наявність значної кількості ЗВО та низьке соціальне забезпечення вчительської праці загальний рівень викладачів молодого покоління, на жаль, є нижчим, аніж показники кінця XX століття. Поняття «учитель за покликанням» у наш час рідкісне явище, й усе, що може педагог вищої школи в роботі зі студентами, 
які все ж обрали педагогічний фах, - це всіляко підвищувати вмотивованість і педагогічну компетентність (Куртова та ін., 2018; Прокопова та ін., 2016).

Деструктивною, на нашу думку, $є$ однобічна переважно предметна вмотивованість абітурієнта під час вступу на той чи інший факультет педагогічного ЗВО й часткове або повне ігнорування на початковому етапі педагогічного аспекту майбутньої діяльності. Особливо це помітно в регіонах країни з відсутністю класичних університетів (Бондаренко, 2008).

Мотивувати учня може тільки той учитель, екологічні компетентності та особистісні властивості якого виглядають природними й фоновими стосовно власне дидактичної діяльності. Екстремумами екологічної активності виступають тільки граничні або когнітивно дисонансні моменти, інакше учень, який рефлексивно сприймає фізичні та психологічні виміри власного здоров'я може вловити «фальш» або нарочиту доцільність у діях педагога (Максимчук та ін., 2018).

Аналіз актуальних досліджень. «Національно свідома українська інтелігенція була налаштована на екологічну підготовку молоді засобами фольклору, етнографічних знахідок, про що свідчать публікації Б. Грінченка, М. Грушевського, І. Франка, у яких ідеться про життя, побут українців, виховання дітей та формування в них мотивації щодо забезпечення здорового способу життя. Така позиція завжди була надійним орієнтиром пошуків нових шляхів та засобів розвитку екологічної освіти» (Волошин, 2012).

Педагогіка вищої школи як давній класичний культурний феномен, звичайно, націлений на деякі ідеальні орієнтири (акмеологія), що виправдано негласною істиною: постановка найвищої моральної чи професійної «планки» забезпечує досягнення достатніх або оптимальних цілей (Куртова та ін., 2018). Отже, мотивація студентів до екологічної активності, діяльності й самовдосконалення містить в основі ціннісні (аксіологічні) імперативи й мотиви. Кожна молода людина на етапі вступу до ЗВО уже має пріоритетні цінності. Більшість із них не відповідають вищим виробленим людською культурою вершинам. Так, наприклад, бути багатим, цікаво проводити час. Бути вільним і незалежним, виражати себе тощо не $є$ загальновизнаними вершинами людських цінностей. Проте їхня вмотивованість у надрах юної особистості виступає як мінімум енергетичним ресурсом, тому студента не треба переорієнтовувати в його цінностях, а необхідно тільки модифікувати наявні в нього орієнтири й рівні домагань у гуманітарне русло (Рибалко та ін., 2018; Соковня-Семенова, 2000).

Прихований цілеспрямований вплив на таку часто неусвідомлену сферу психіки, як мотивація, має бути усвідомленим хоча 6 із однієї суб'єктної сторони, у нашому випадку - викладача, який розуміє, що «ідеальне уявлення бажаного результату відображається в понятті «мета». Життєві, моральні та естетичні імперативи, вироблені людською культурою й 
визнаються в суспільстві як загальнозначущі, $є$ цілями високого рівня і називаються також соціальними цінностями. Ті соціальні цінності, що виступають для людини в якості стратегічних цілей їі діяльності, називають ціннісними орієнтаціями особистості. Вони посідають найвищий, визначальний щабель у мотиваційно-регулятивній системі, бо виконують функцію довгострокового визначення поведінки та діяльності людини; роблять життя осмисленим і послідовним, визначаючи зміст та спрямованість більш конкретних регуляторів - потреб, мотивів і інтересів» (Пакушина, 2010).

Науковці намагаються зрозуміти причину відносно низької екологічної компетентності майбутніх-педагогів (Bakhmat et al., 2019; Maksymchuk et al., 2018; Міхеєнко, 2004). Низький рівень сформованості екологічної компетентності студента педагогічного університету характеризується відсутністю інтересу; мотивація до збереження власного здоров'я і здоров'я оточуючих носить вимушений характер. Такі студенти демонструють поверхові, фрагментарні екологічні знання без наукового підґрунтя, деякі з них помилкові, що базуються на примітивно-побутовій основі. Вважають за непотрібне самостійне «здобування» нових екологічних знань, тому самоосвіта потребує постійного заохочення. Такі студенти мають шкідливі звички, спостерігається їх демонстративне пропагування й небажання щось змінювати. Якщо приймається рішення про внесення змін у дезадаптивну поведінку, то екологічна діяльність не проводиться 3 причини несформованих відповідних навичок. Відповідальність за такі дії або відсутня, або повністю перекладається на інших людей» (Пакушина, 2010).

Методологи вищої школи зрозуміли, що акмеологічна (висока) сутність ціннісних орієнтирів має бути спрощена й адаптована до реалій життя і щоденного педагогічного процесу і не мають дисонувати з іншими аспектами життєдіяльності студента. Так, О. Поташнюк (2000) робить цінне узагальнення: «Практика управління навчальним процесом потребує, щоб характеристики ефективності виявлялись у легко вимірюваних і простих показниках, які повинні задовольняти такі основні вимоги: а) відображати як результативні, так і процесуальні характеристики навчальної діяльності студента і зміни в них, указувати не тільки результати, але й те, якою «ціною» він досягнутий; б) бути взаємопов'язаними, тобто складати певну цілісну систему; в) бути виведеними як наслідок із основних дидактичних принципів навчання і виховання, навчання та розвитку тощо; г) бути соціально і психологічно значущими; мати сенс як для студента, так і викладача; д) бути простими в розумінні, легко вимірюваними, тобто методики для вимірювання повинні бути простими, щоб їх міг використовувати викладач, який не має спеціальної психологічної освіти».

Тактично більш валідним і дієвим поняттям $є$ установка на поведінку, що на відміну від паттернів (звичних рефлекторних форм реагування й поведінки на типові ситуації) дозволяє суб'єктові освітнього процесу 
поступово і рівномірно видозмінювати спочатку реакцію, а потім активність. Потім - поведінку, діяльність, світогляд тощо.

О. Бондаренко (2008), який вивчав формування компетентності студентів педагогічних університетів у процесі професійної підготовки, дійшов висновку, що установка на будь-яку форму поведінки, у тому числі й раціональну, ураховує два моменти: мета повинна сприйматися як життєво необхідна і бути досяжною, тобто результат поведінки повинен набути статусу життєво необхідного, бути прогнозованим та реальним. Установка визначає готовність людини до певних дій і формується на основі мотивації.

Мета статті полягає в теоретичному обґрунтуванні ефективності активізації мотивації майбутніх викладачів фізичного виховання і спорту в сфері екологічного туризму.

Методи дослідження: теоретичні - аналіз і синтез літературних джерел, порівняння, систематизація, узагальнення, абстрагування, гіпотетико-дедуктивний, індивідуалізація, класифікація, аналогії, моделювання, прогнозування з метою вивчення концептуальних положень для обґрунтування авторської концепції.

Виклад основного матеріалу, у межах проведеного нами експерименту було з'ясовано, що найбільш ефективною $є$ така педагогічна діяльність викладача, за якої вже наявні в молодої людини потреби, а відповідно, і мотивації до активності, модифікуються й трансформуються в більш ціннісні та професійні. Педагоги і психологи зазначають: «Потреба може перебувати у двох станах: латентному (не проявляє себе) i актуалізованому (прояв потреби шляхом емоційного напруження, що передбачає ії негайне задоволення)» (Бондаренко, 2008). Психоемоційне, фізичне або інтелектуальне напруження сигналізує про усвідомлену або приховану мотивацію активності, тому формування поведінкової установки у студента на здоровий спосіб життя і засвоєння пов'язаних із цим компетентностей можливе не в боротьбі проти різноманітних потреб, а скеровуванні їх у структуроване русло. На додіяльнісному рівні - це формування настрою, психологічного стану, установки, бажання (наприклад, бути успішним, кращим, здоровим), ставлення (до себе, інших, світу), позитивних установок, імпульсу до початку активності, а вже потім -діяльності, скерованої на позитивне перетворення себе, світу і людей, із якими спілкуєшся.

У сучасних студентів мотивація навчальної діяльності, згідно з опитуваннями та спостереженнями, часто носить формальний характер: здобути вищу освіту, одержати престижний диплом, цікаво провести час юності, виправдати сподівання батьків, соціалізуватися тощо. Спільний знаменник такого, навіть формального, мотивування освітньої діяльності $\epsilon$ успіх, щось позитивне. «Тому апелювання до символів успіху може підсилювати потребу в досягненнях лише за умови, коли ці символи будуть основою для прийняття рішень про майбутній професійний статус і 
основою престижу випускника. На сучасному етапі фахівці отримують диплом звичайний або диплом з відзнакою. Більш детальна категоризація сприяла би розвитку мотивації досягнення через символи успіху, що фіксуються в документах майбутнього фахівця» (Поташнюк, 2000).

Такий мультиакцентний підхід видається виправданим і $є$ більш зрозумілим, якщо усвідомити певну ієрархію фізичних, когнітивних та мотиваційних особливостей студентів різних курсів: студент-першокурсник має певний ще не сформований до кінця фізичний, духовний та інтелектуальний базис і отримує в межах університетської програми знання з основ медичних знань, шкільної гігієни, фізичної культури, історії культури, філософії (I - III курси). 4 курс бакалаврату характеризується акцентом на методології викладання обраних дисциплін та шкільну виробничу практику, у межах яких майбутній учитель уже повинен окреслити екологічну складову, а головне, керуватися на потребу й мотивацію. Тут можна окремо схарактеризувати напрями підготовки викладачів фізико-математичного й гуманітарного напрямів, які не вивчають антропологічно орієнтованих дисциплін, окрім загальних; викладачів природничого циклу, які одержують знання з біології, фізіології, анатомії, біохімії тощо й викладачів фізичної культури, які отримують найбільше пов'язаних із валеологією знань.

І. Соковня-Семенова (2000) у своїй праці виокремлює 7 типів мотивацій людини, яка обирає й дотримується екологічної поведінки. Їх можна резюмувати до таких комплікованих понять: самозбереження, задоволення, гармонія із суспільством (дотримання моральних норм, традицій), самовдосконалення, гнучкість (зміна соціальної ролі), сексуальна реалізованість та комфортність. Це наштовхує на кілька дуалістичних міркувань: а) можна впливати на екологічну вмотивованість, а можна на мотиваційну сферу в цілому; б) можна мотивувати екологічну діяльність високими цінностями (ідеї, акмеологія), а можна низькими й навіть аліментарними (задоволення, комфорт).

Науковець зробила у своєму дослідженні висновок: «Доцільно буде проектувати діяльність педагога на мотиваційну сферу в цілому, а не екологічну вмотивованість студента. Психологами давно доведено, що будь-яка діяльність людини, навіть негативна, мотивована позитивними установками або цілями» (Поташнюк, 2000).

У процесі виробничої діяльності будь-який компетентний педагог зрозуміє, що створення мотивації - це не окремий і тим більше не явний декларований процес. Багато педагогів-початківців узагалі підсвідомо протиставляють освітній процес іншим сферам життя, транслюючи максиму: «будеш гарно вчитися, то будеш добре жити». Насправді, ці аспекти нероздільні. 
О. Міхєєнко (2004) зазначає: «Освітній процес - це процес передачі та отримання знань і вмінь, підкріплений їх добуванням. А добування знань, створення нових знань та вмінь - це процес фундаментального дослідження, причому безвідносно до того - прикладного чи абстрактного. Для того, щоб цей процес відбувався, необхідна особлива атмосфера інтелектуального особистого спілкування і не тільки на рівні учень викладач, але й у взаємодії викладач - викладач, учень - учень.

Найбільш поширена помилка в освіті, на думку більшості фахівців, полягає в недооцінці природної основи людини, яку майже завжди сприймають не як союзника, а як матеріал, що протистоїть педагогічному впливу і який необхідно змінити» (Махеєнко, 2004, с. 77). Психологічновікова особливість підлітків (середні і старші класи середньої школи) і ранньої молоді (студенти) полягає у глибокій упевненості в цінностях молодіжної субкультури і певне протиставлення їх загальнолюдським. Завдання викладача на шляху до формування особисто позитивної студентської вмотивованості у валеологічно орієнтованому житті скоригувати дещо максималістське й інфантильне уявлення про вказані цінності та переконати: всі люди (батьки, викладачі, студенти, учні) йдуть в одному напрямку, але різними, часом екстенсивними шляхами.

Викладач 3 ВО і вчитель закладу загальної середньої освіти може скласти суб'єктивну картину на основі досвіду слідкування з учнем та спостереження за ним. 3 одного боку, сам учень/студент в ідеалі повинен із власної мотивації вести так звану «екологічну картку», проте досвідчений педагог складає свідомо або несвідомо екологічну картину (враження) кожного вихованця, групи, класу, курсу тощо.

Висновки. Еко-туризм є невід'ємною складовою загальнодержавної системи фізичної культури та спорту і спрямований на зміцнення здоров'я, розвиток фізичних, морально-вольових та інтелектуальних здібностей людини через залучення ії до участі у спортивних походах різної складності та змаганнях.

Затверджена Постановою Виконкому Федерації туризму України «Положення про систему підготовки кадрів», як багаторічна система підготовки кадрів з туризму в Україні працює епізодично і не дає тієї туристсько-спортивної підготовки, яку вимагає на сьогодні ринок подорожей із активними засобами пересування.

Така підготовка повинна передбачити врахування здобутків природничих і суспільно-гуманітарних наук із боку викладача, основною проблемою кореляції яких $€$ діалектична взаємодія соціально-культурного й природного в людині.

Правовим аспектом $€$ реалізація прав людини на освіту, медичну допомогу, реалізацію своїх потреб і здібностей, захист навколишнього середовища тощо. При цьому домінантною $є$ виховний, а не дидактичний 
компонент. У цьому плані на перших заняттях з фізичного виховання у педагогічному ЗВО пропонується студентам завести індивідуальну карту.

Якщо раніше вже відбувалися в закладах середньої і вищої освіти практики з ведення індивідуальних карток здоров'я, то ми, у свою чергу, пропонуємо вести паралельні (у викладача і у студента) розширені індивідуальні карти, що матимуть обов'язкову (анкетну) й варіативну частину, а також часову таблицю змін.

\section{ЛІТЕРАТУРА}

Bakhmat, N., Maksymchuk, B., Voloshyna, O., Kuzmenko, V., Matviichuk, T., Kovalchuk, A., Maksymchuk, I. (2019). Designing cloud-oriented university environment in teacher training of future physical education teachers. Journal of Physical Education and Sport, 19 (4), 1323-1332.

M aksymchuk, I., M aksymchuk, B., Frytsiuk, V., Matviichuk, T., Demchenko, I., Babii, I. Savchuk, I. (2018). Developing pedagogical mastery of future physical education teachers in higher education institutions. Journal of Physical Education and Sport, 18 (2), 810-815.

Бондаренко, О. М. (2008). Формування валеологічної компетентності студентів педагогічних університетів у процесі професійної підготовки (дис. ... канд. пед. наук: 13.00.04). Київ (Bondarenko, О. М. (2008). Formation of valeological competence of students of pedagogical universities in the process of vocational training (PhD thesis). Kyiv).

Волошин, О. Р. (2012). Розвиток валеологічної освіти на західно українських землях (1918-1939 рр.) (дис. ... к. пед. н: 13.00.01). Дрогобич (Voloshyn, O. R. (2012). Development of valeological education in Western Ukrainian lands (1918-1939) (PhD thesis). Drogobych).

Максимчук, Б. А., Галайдюк, М. А., Максимчук, І. А. (2018). Валеологічний саморозвиток та активація мотивації майбутніх фахівців до формування валеологічної компетентності в умовах глобалізаційних та інтеграційних процесів. Особистісно-професійний розвиток майбутніх фахівців соціономічних професій в умовах трансформації суспільства. Вінниця: ТОВ «Нілан-лТД» (Maksymchuk, B. A., Galaidiuk, M. A., Maksymchuk, I. A. (2018). Valeological selfdevelopment and activation of motivation of future specialists for the formation of valeological competence in the conditions of globalization and integration processes. Personal-professional development of future specialists of socio-economic professions in the conditions of transformation of society. Vinnytsia: Nilan LTD).

Міхеєнко, О. І. (2004). Валеологічна підготовка майбутніх фахівців з фізичної реабілітації у вищому педагогічному навчальному закладі (дис. ... канд. пед. наук: 13.00.04). Суми (Mikheienko, O. I. (2004). Valeological training of future specialists in physical rehabilitation at the higher pedagogical institution (PhD thesis). Sumy).

Пакушина, л. 3. (2010). Формування валеологічної грамотності майбутніх соціальних педагогів у процесі професійної підготовки (дис. ... канд. пед. наук: 13.00.04). Черкаси (Pakushyna, L. Z. (2010). Formation of valeological literacy of future social pedagogues in the process of vocational training (PhD thesis). Cherkasy).

Поташнюк, І. В. (2000). Професійна валеологічна підготовка майбутніх біологів у вищих закладах освіти III-IV рівнів акредитації (дис. ... канд. пед. наук: 13.00.04). Луцьк (Potashniuk, I. V. (2000). Professional valeological training of future biologists in higher educational establishments of III-IV levels of accreditation (PhD thesis). Lutsk). 
Рибалко, П. Ф., Ганчева, В. І., Жуков, В. Л. (2018). Теоретичні та методичні засади рекреації та оздоровлення підлітків засобами активного туризму. Вісник Чернігівського національного педагогічного університету. Серія: Педагогічні науки, 151 (2), 123-126 (Rybalko, P. F., Hancheva, V. I., Zhukov, V. L. (2018). Theoretical and methodological foundations of recreation and rehabilitation of teenagers by means of active tourism. Bulletin of Chernihiv National Pedagogical University. Series: Pedagogical Sciences, 151 (2), 123-126).

Куртова, Г., Рибалко, П., Красілов, А. (2018). Педагогічні умови формування здоров'язбережувальної компетентності фахівців аграрного сектору у процесі фізичного виховання. Педагогічні науки: теорія, історія, інноваційні технології, 4, 100-111 (Kurtova, H., Rybalko, P., Krasilov, A. (2018). Pedagogical conditions of formation of health-saving competence of specialists of agrarian sector in the process of physical education. Pedagogical sciences: theory, history, innovative technologies, 4, 100-111).

Прокопова, Л. І., Гученко, А. Б., Гвоздецька, С. В., Рибалко, П. Ф. (2016). Формування професійної майстерності майбутнього вчителя фізичної культури. Вісник Чернігівського національного педагогічного університету імені Т.Г. Шевченко. Серія: Педагогічні науки, 135, 213-216 (Prokopova, L. I., Huchenko, A. B., Hvozdetska, S. V., Rybalko, P. F. (2016). Formation of professional skill of the future physical education teacher. Bulletin of Chernihiv National Pedagogical University named after T.G. Shevchenko. Series: Pedagogical Sciences, 135, 213-216).

Соковня-Семенова, И. И. (2000). Основы здорового образа жизни и первая медицинская помощь. Москва: Академия (Sokovnia-Semenova, I. I. (2000). The basics of a healthy lifestyle and first aid. M oscow: Academy).

\section{PEЗЮME}

Максимчук Борис, Жуков Владимир, Ящук Сергей, Зубаль Майя, Кевпанич Василий. Активизация мотивации будущих преподавателей физического воспитания и спорта в сфере экологического туризма.

Мотивировать ученика может только тот преподаватель, экологчческие компетентности и личностные качества которого выглядят естественными и фоновыми относительно собственно дидактической деятельности. Экстремумами экологической активности выступают только пограничные или когнитивнодиссонансные моменты, иначе студент, который рефлексивно воспринимает физические и психологические измерения, может увидеть «фальшь» или умышленную целесообразность в действиях педагога. Мотивация студентов к экологической активности, деятельности и самосовершенствованию содержит в основе ценностные (аксиологические) императивы и мотивы. Цель статьи заключается в теоретическом обосновании эффективности активизация мотивации будущих преподавателей физического воспитания и спорта в сфере экологического туризма.

Ключевые слова: компетентность, студенты, высшие учебные заведения, активное обучение, методы обучения, мотивы, ценности, высшая школа. 


\section{SUM MARY}

Maksymchuk Borys, Zhukov Vladimir, Yashchuk Serhii, Zubal Maya, Kevpanych Vasyl. Enhancing the motivation of future physical education teachers in the field of ecotourism.

Only the university teacher whose ecological competences and personal qualities may appear to be natural and background regarding didactic activities can motivate the student. The turning points of ecological activities are only borderline or cognitively dissonant moments, otherwise, the student who reflexively perceives physical and psychological dimensions may see "falsehood" or intentional expediency in the actions of the university teacher. Students' motivation towards ecological activities and self-improvement is based on axiological imperatives and motives. The article aims to theoretically justify the effectiveness of enhancing the motivation of future physical education teachers in the field of eco-tourism. Research methods include the following: theoretical methods - analysis and synthesis of literary sources, comparison, systematization, generalization, abstraction, hypothetical method, deduction, individualization, classification, analogies, modelling, forecasting to study conceptual provisions to substantiate the author's concept. The process of enhancing the motivation of the EG students and university teachers was based on such author's methodologies as "The Questionnaire for Teachers to Study Their Ecological Health", "The Questionnaire to Study Students' Attitude towards Eco-Tourism", "The Questionnaire to Study Teacher and Students' Readiness towards Development of Eco-Tourism", "The Questionnaire to Identify the Formation Level of the Axiological and M otivational Component of Eco-Tourism Development", "M ethods for Determining the Role of Health-Related Values in the Hierarchy of Students' Vital Values", "The Text of the Questionnaire for Revealing Students' Awareness of Ecological Health", "The Diagnostics of Volitional Self-Control (A. Zverkov and E. Eidman's Questionnaire)", etc. The following methods were used to develop ecological competences in future teachers: writing essays, analyzing and selecting topics for instructional design within the interdisciplinary project "Ecology and Health". The affirmation of behavior is tactically more valid and effective, which, unlike the patterns (habitual reflexive forms of reaction and behavior in typical situations) allows the participant in the educational process to gradually and uniformly modify the first reaction, activity and, subsequently, behavior, actions, mindset, etc.

Key words: competence, students, higher education institutions, active learning, teaching methods, motives, values, higher education.

Удк 378.09.011.3:373.2.091.12-051

Леся Мороз-Рекотова

Бердянський державний педагогічний університет

ORCID ID 0000-0001-5161-721X

DOI 10.24139/2312-5993/2019.07/243-254

\section{КРИТЕРІЇ, ПОКАЗНИКИ ТА РІВНІ СФОРМОВАНОСТІ ПРОФЕСІЙНО- КОМУНІКАТИВНОЇ КУЛЬТУРИ МАЙБУТНІХ ВИХОВАТЕЛІВ ЗАКЛАДІВ ДОШКІЛЬНОї ОСВІтИ}

У статті подано уточнене визначення професійно-комунікативної культури майбутніх вихователів закладів дошкільної освіти, зазначено їі структурні 